\title{
LANDSCAPE AESTHETIC AND VISUAL ANALYSIS FACING THE CHALLENGE OF DEVELOPMENT OF SUSTAINABLE LANDSCAPES - A CASE STUDY OF THE POST-INDUSTRIAL AREA TO THE LEFT MARGIN OF THE ARADE RIVER
}

\author{
L. LOURES, P. VARGUES \& D. HORTA \\ Department of Landscape Architecture, Faculty of Engineering of Natural Resources, \\ University of Algarve, Faro, Portugal.
}

\begin{abstract}
It is increasingly recognized that growing demands for diverse, multifunctional and quality recreation landscapes have placed a high pressure on the natural resources and its management. This fact coupled with the current common way of perceiving landscape as something separate from us, with several functions for society and individuals - in spite of something that changes automatically according to cultural, economic and social changes, enhances the necessity for developing new approaches and methodologies that effectively apply sustainable principles to landscape monitoring, planning and management. For this reason, adequate information about the existing landscape and about the nature of places that it is desirable to make cannot be the result of superficial approaches based exclusively on designers and planners' ideas. Even if planning and monitoring programs frequently use remote sensing data and focus only on changes in land cover and land use in relation to values such as biodiversity, land capability and recreation, they often neglect landscape aesthetics, cultural heritage and public will. To show that it is possible to combine all these factors in a specific approach, this paper presents a specific study of the estuarine landscape of the Arade River in Algarve, Portugal, based on a methodology that incorporates SWOT (strengths, weaknesses, opportunities and threats) analysis and aesthetic, cultural, biophysical and social factors in landscape assessment.

Keywords: landscape aesthetics, landscape quality assessment, SWOT analysis.
\end{abstract}

\section{INTRODUCTION}

It is increasingly recognized that landscape managers, environmental specialists, non-profit environmental organizations, governmental agencies and citizens are interested in scientific tools to assist in environmental studies and analysis. For this reason, in the last two decades, visual and aesthetic research studies frequently focused on special modelling tools and techniques to reproduce three-dimensional environmental qualities [1-10].

Aesthetics, a concept developed by the western civilization, has been a subject of debate for philosophers and artists from the time of the ancient Greece and more recently for architects, urban and environmental managers and even policy makers [11]. Although artists were the first to begin to transform this sensitive surface, seeking a type of formal assimilation for everyday use, it was the architects who attempted to define, using the same approach, a method capable of reacting and integrating aesthetics into the life of man and in the spaces that protect him [12].

Recently many landscape architects and other environmental specialists have begun to look at the landscape not only as a setting in which to intervene, inserting an indefinite variety of objects, but also as a tool through which to design and manipulate complex material. Understanding the aesthetic character of any landscape and design solutions, as well as a design process that facilitates a fair representation of the existing landscape attributes, is paramount for success [13]. These facts turned the landscape into something different, a place sensitive to different transformations, which records the movements and events that cross it.

(C) 2008 WIT Press, www.witpress.com

ISSN: 1755-7437 (paper format), ISSN: 1755-7445 (online), http://journals.witpress.com DOI: 10.2495/D\&NE-V3-N1-65-74 
In this sense, aesthetic expectations ought to be considered in a thoughtful design. To achieve this, a careful understanding of visual and non-visual environmental aesthetics is necessary, knowing that colour, form, line and texture are characteristics that define visually and aesthetically any object or landscape [14]. The use of landscape attributes is even more essential in landscapes that have been previously developed and where it is necessary to perform specific reclamation work. For this reason, this paper presents a particular study of the estuarine post-industrial landscape to the left margin of the Arade River in Algarve, Portugal. To analyse, assess and describe this locally, regionally and nationally significant landscape, numerical values were used to assign factors such as vegetation, slope, sun exposure, observation distance, visual magnitude and human activities, as well as a brief SWOT (strengths, weaknesses, opportunities and threats) analysis, based on aesthetic, cultural and social information, investigating the current and future possibilities for this landscape.

\section{THE ROLE OF AESTHETICS IN THE SUSTAINABLE RECLAMATION OF POST-INDUSTRIAL LANDSCAPES}

It is widely acknowledged that future reclamation activities may be in consultation with a global land-use planning and design agenda for climatic stability, sustainable food sources, renewable natural resources and protection of the globe's inhabitants [15]. However, the role that aesthetic and visual analysis can play in the reclamation of post-industrial landscapes is not well developed. As it is generally recognized, industry is one activity that can occur practically anywhere on the planet's surface [16]. This reality coupled with the fact that in the past industry was often abandoned without performing any reclamation work turned the reclamation of post-industrial landscapes into one of the biggest challenges in several urban landscapes.

Even derelict and degraded industrial areas can be created with a new spirit and can be made worth living by keeping visible the spirit of the existing site, by applying design strategies that enhance the aesthetic landscape attributes and contribute to economic prosperity, social cohesion and environmental quality $[17,18]$. Aesthetic influences upon landscape reclamation projects include the landscape of the locality, traditional influences in landscape design and various theoretical approaches [19]. Aesthetic values are inherent in things. Things emanate from them, just as odours do from food or from flowers. And like tangible perfumes, they determine our sensitive or emotional reaction. Aesthetic values influence us at all moments. Consciously, or in most cases subconsciously, they provoke friendly or hostile reactions. They escape from our rationalistic strongholds, directly back to our emotions and therefore are out of our control [19]. This means that aesthetic values are no simple trimmings, but indeed have their roots in the depth of the soul. Their impact on man's decisions reaches even into the most practical problems, into the shaping of things of daily use and above all, of our human environment.

\section{METHODOLOGY}

The primary task of the visual and aesthetic analysis was the definition of a specific study area. To define this area, we generated a digital terrain model (DTM) for the municipality of Lagoa, using ArcGIS 9.2 from digitalized contour maps. From the final DTM, the potential intervisibility of the area was studied, and the two-dimensional maps (viewsheds) of all visible areas both from the river line between Ferragudo and Fontes (assessing mutually the visibility from the river and from the city of Portimão, the second largest city of Algarve) and from 10 different view points, at a given height $(1.70 \mathrm{~m}-$ the approximate average height of the Portuguese population). The viewpoints were located according to relevant landscape features, as is the case of several industrial buildings with historic value, tide mills, salinas and marshes, among others (Fig. 1). 


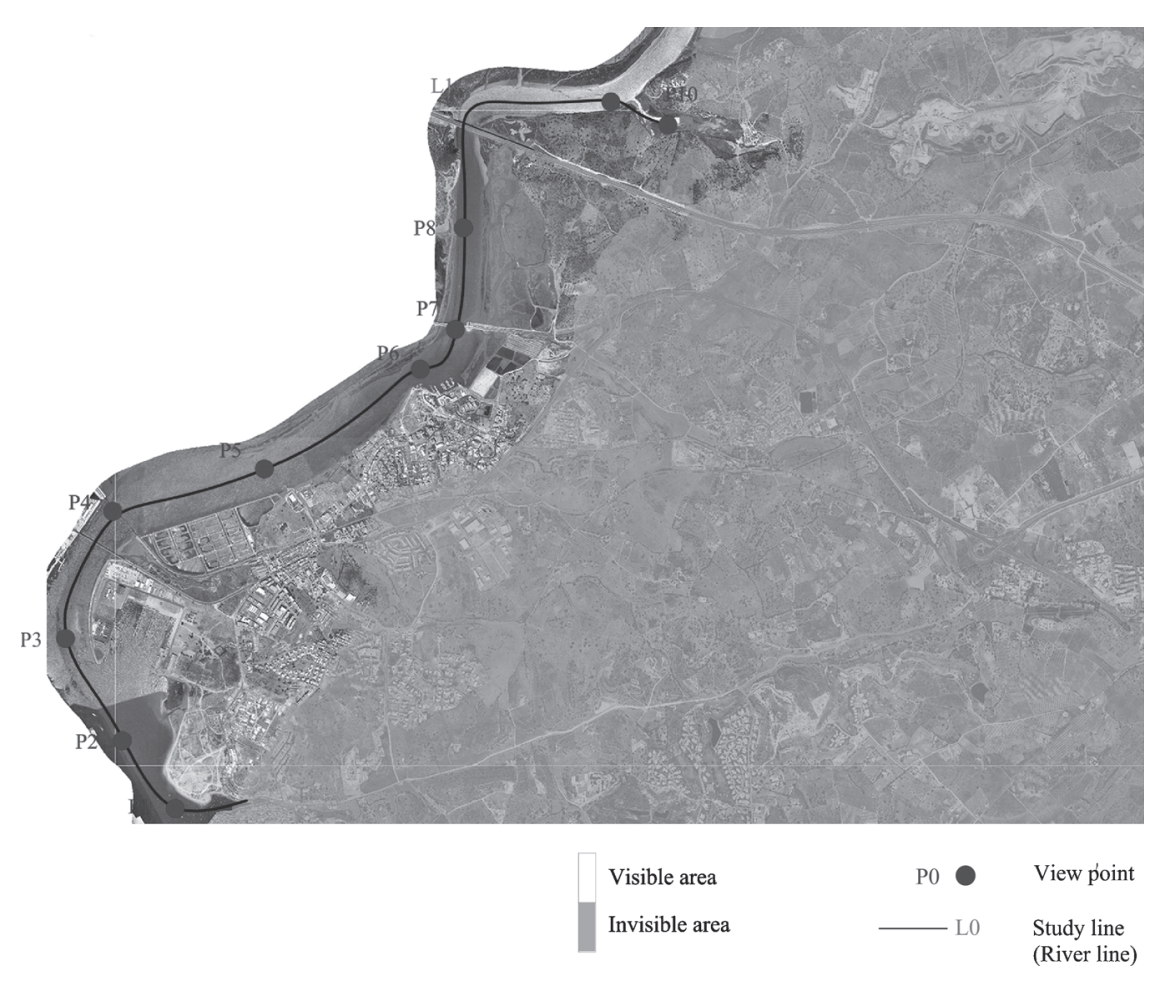

Figure 1: Viewshed map.

After the definition of the study area and of the view points, landscape units were identified, according to criteria of relative homogeneity, biodiversity, identity and sensation developed by the landscape architect Cancela D'Abeu [20] (Fig. 2). The quality and visual absorption capacity of the view points and of the river line were evaluated, assessing the visibility impact of the different landscape units and giving some clues for future land uses that will keep potential impacts to a minimum. The landscape quality survey embraces the study of environmental features, human perception or experience and biophysical interacting components [21].

To assign factors such as slope, vegetation, fragmentation, observation distance, human activities and visual magnitude, numerical values were used, to analyse, evaluate and characterize the landscape $[15,22,23]$. To assess landscape visual sensitivity and quality, a numerical rate was used - indicating low (1), fair (2), high (3), and very high (4) visual sensitivity and quality - and the obtained information was used to create digital maps.

Furthermore, visual simulation in three dimensions was elaborated and a fly-over digital video was made to visualize and get a better perception of the study area as well as a SWOT analysis was performed, presenting the potential benefits of the implementation of a reclamation project in this landscape.

\section{A BRIEF DESCRIPTION OF THE STUDY AREA - LEFT MARGIN OF THE ARADE ESTUARINE LANDSCAPE}

The estuarine post-industrial landscape to the left margin of the Arade River is located in the municipality of Lagoa, Algarve, which is characterized by a Mediterranean climate and landscapes. Algarve is located in the southern region of Portugal with $22 \%$ of the land occupied by forests and 


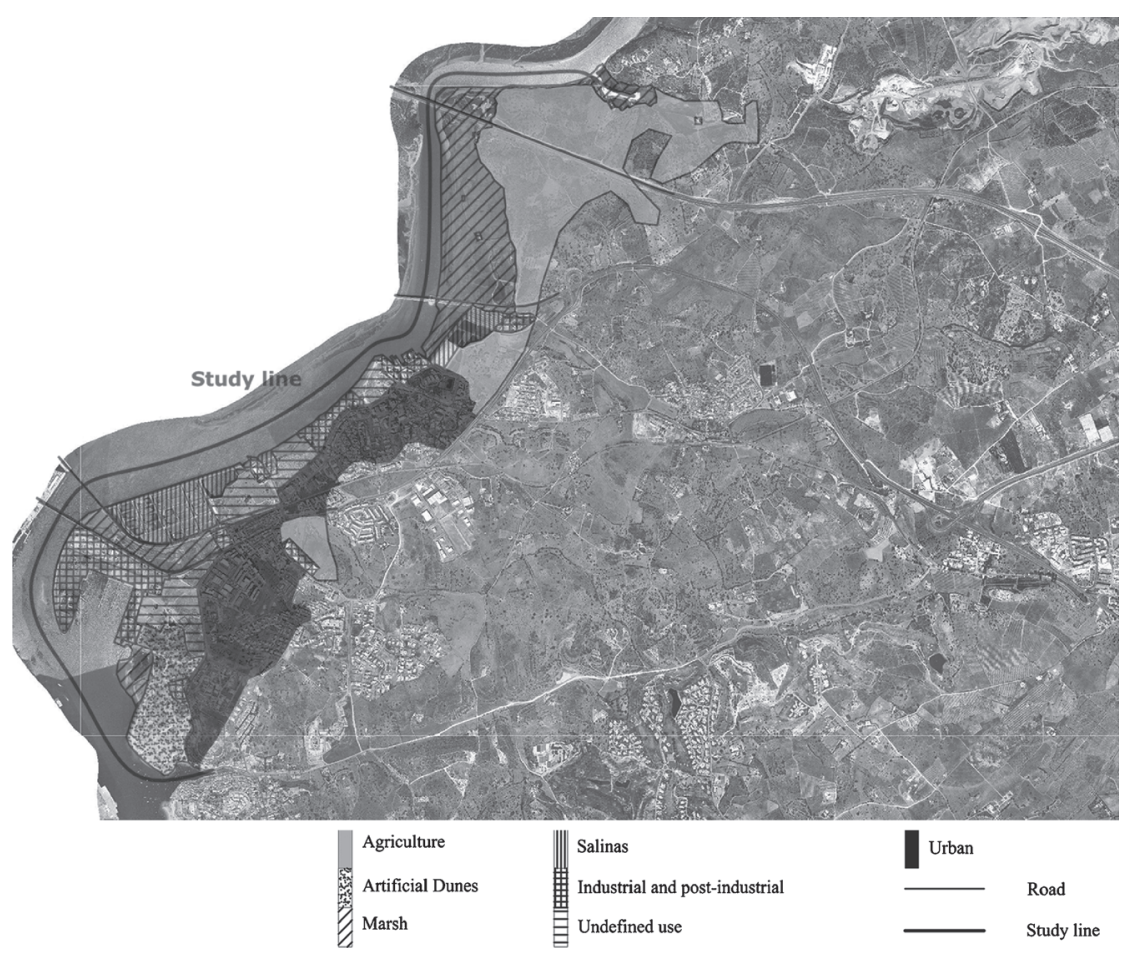

Figure 2: Landscape units.

$38 \%$ by uncultivated maquis and gariques. In Algarve, the main species are Citrus sp., Quercus suber, Quercus ilex, Seratonea siliqua and Pinus pinaster. The population is characterized by a decreasing and scattered distribution in the mountainous areas and is concentrated in the coastal zones. Tourism is the main activity and the farming population is continuously ageing.

The importance of the Arade River and its surroundings in the local, regional and national context can be attested by several archaeological tracks that have been found submerged and around it. However, it was only in the beginning of the twentieth century that the implantation of an industrial centre in the river margins promoted some development of the area. The circumstance of the First World War had great importance for the development of this industry, once it absorbed all the production. At this time, almost two-thirds of the population worked in industry [24]. Even so, during the 1960s, the industrial activity collapsed and numerous industrial structures were left abandoned. The destiny of this whole industrial landscape is still unknown, although during the last decade some of the interventions that had been accomplished contributed to the disappearance of some buildings with significant meaning. In this way, it is essential to accomplish a group of coordinated actions that allow the recovery of this post-industrial landscape. Unlike explanations that tend to become dominant, the reclamation of the industrial landscape of the Arade River is not just a type of insurance against forgetfulness [25]. It is an instrument of social legitimation [26, 27] and a strategy to reclaim and redevelop a post-industrial site to turn it into a multifunctional landscape [28-30]. This industrial area describes today more than a hundred years of local and regional history, constituting a testimony to an industrial, cultural and social conception and evolution, which documents and interprets considerable values for the industrial heritage of Algarve. 


\section{RESULTS AND DISCUSSIONS}

Using aerial photos and in situ observations, the landscape of the estuarine area and its surrounding was divided into seven units: A - agriculture, B - artificial dunes, C - marsh, D - salinas, E - industrial and post-industrial, $\mathrm{F}$ - undefined use and $\mathrm{G}$ - urban, to analyse the visual quality and fragility of each landscape unit (Table 1).

According to the used criteria, visual quality is the capacity of a landscape not to change and to maintain its structure, while fragility is the degree of susceptibility to transformation.

With regard to the visual quality (Table 1) and according to the used parameters, the industrial and post-industrial, the urban and the artificial dune landscape units present low quality; the unit with undefined use presents fair quality; the marsh and the salinas units present high quality and agriculture a very high quality. With regard to landscape fragility, the most fragile units are agriculture and marsh, while urban and artificial dunes are those that present low sensitivity.

Next, 11 viewsheds of the studied area were calculated at selected key view points to analyse the visual absorption capability (VAC) (Table 2). As this analysis is dependent on the 'eye of the beholder', each one of the authors developed an individual table to reduce possible outliers resulting from individual perception or experience. In this way, the values presented in Table 2 are an average obtained from three different tables.

According to the selected parameters (observation position, observation distance, visualization time, landscape type and slope), point number 4 (P4 - located on the railroad bridge that connects both margins of the Arade River) and the river line ( $\mathrm{RL}$ - delineated between both margins along the study area, representing the viewshed obtained in a boat trip along the river) present an average VAC and all the other view points present low VAC.

By analysing Table 2, it is possible to verify that at the view points P2, P3, P5, P6 and P9, the low VAC is directly influenced by the observation distance $(0-400 \mathrm{~m})$ and by the visualization time (>30 s). At the view points P7 and P8, the low VAC is inherent to a very characteristic landscape type (salt marsh and salinas) and to visualization time (>30 s). Furthermore, as one may notice, the parameters observation position and visualization time are constant. With regard to the observation position, this constancy is inherent in the fact that there is no significant variation among different points. For this reason and once the observation position is normal, an average value of 3 was assigned. With regard to visualization time, according to the established parameters, a maximum visualization time should be attributed to every point once the observer can stay at the same place as long as he wishes.

Based on the presented results, any intervention or reclamation project developed in this area ought to be extremely careful and take into consideration the aesthetics and the character of the place.

Table 1: Visual quality and fragility of landscape units at the study area.

\begin{tabular}{lclcl}
\hline Landscape units & Quality & Class & Fragility & Class \\
\hline Agriculture & 3 & Very high & 3 & Very high \\
Artificial dunes & 1.87 & Low & 2 & Low \\
Marsh & 2.62 & High & 2.83 & High \\
Salinas & 2.5 & High & 2.16 & Fair \\
Industrial and post-industrial & 1.25 & Low & 2.16 & Fair \\
Undefined use & 2.12 & Fair & 2.66 & High \\
Urban & 1.45 & Low & 1.30 & Low \\
\hline
\end{tabular}




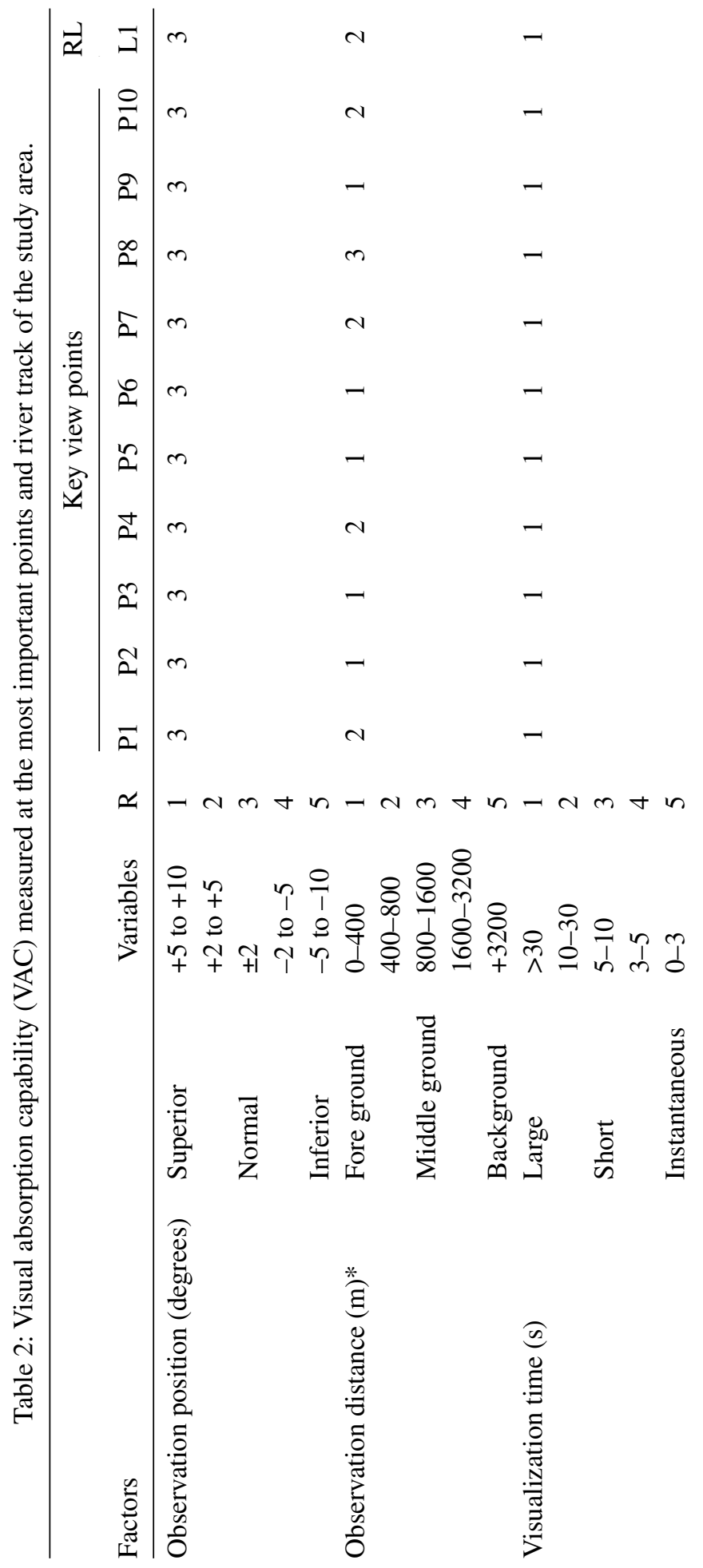




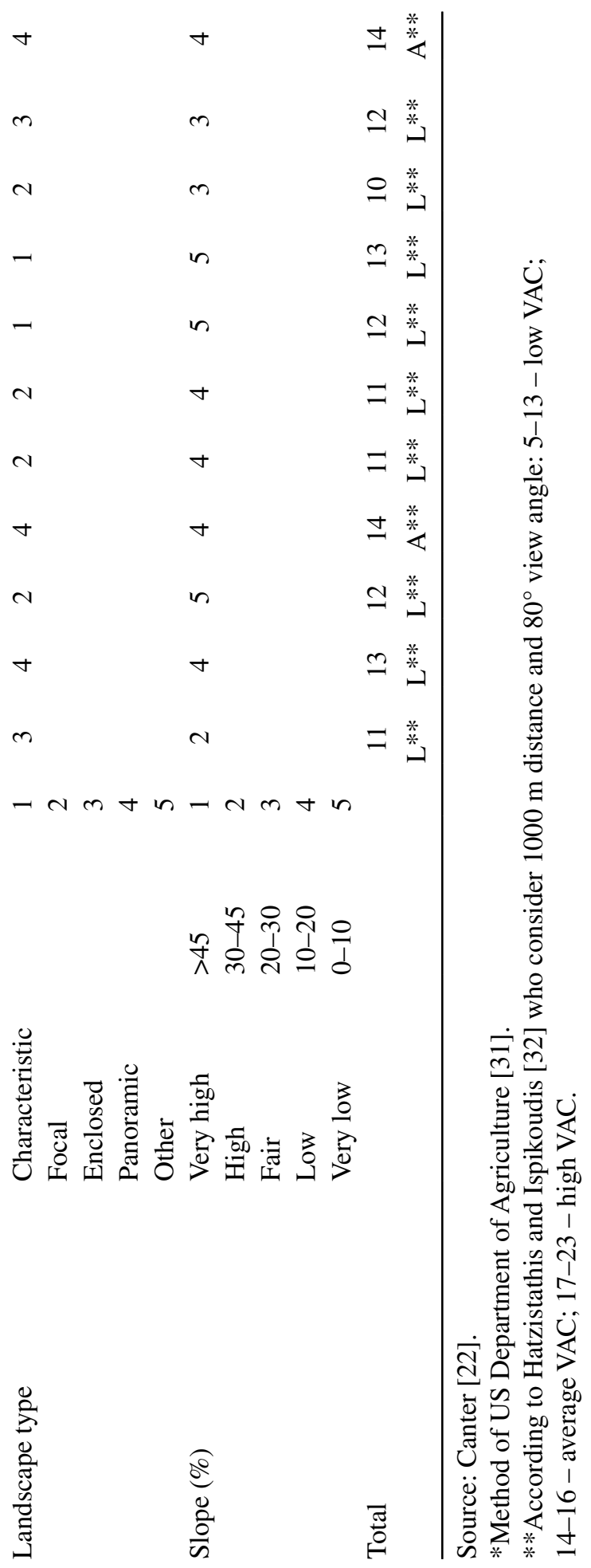


Table 3: Brief SWOT analysis.

\begin{tabular}{ll}
\hline Strengths & Possibility to use natural resources \\
& - High geographical possibilities at local and regional levels \\
& - Soil and climate characteristics and high bio-energy potential \\
Weaknesses & - Illogical use of space \\
& - Lack of specific principles for urban renewal \\
& - Difficulty to convince the state (municipality) for immediate funding to reclaim \\
& derelict land \\
Opportunities & - Use of sun and wind energy \\
& - Increase soil and water quality \\
& - Multipurpose use of water \\
& - Possibilities of reusing derelict areas in spite of consuming new ones \\
& - To create a wide range of recreational facilities \\
Threats & To redevelop the old industrial landscape by enhancing the linkage between the \\
& - Lack of awareness of the importance of estuarine landscapes for ecological \\
& balance and stability of the area \\
- Limited possibilities of financing support for municipal development & Lack of political will to establish and finance funds and institutions to support \\
& cultural and environmental development
\end{tabular}

This fact added to the principal strengths, weaknesses, opportunities and threats of this landscape, identified during the realization of the SWOT analysis (Table 3), presents landscape architects, urban planners, environmental engineers and other environmental specialists with a huge challenge, related to the need to redevelop this landscape, achieving both the reclamation of the abandoned industrial areas and the maintenance of the spirit of the place.

\section{CONCLUSIONS}

Today, with the increased ability to disturb and affect large portions of the landscape, there is deep public concern about the necessity to develop scientific frameworks and methods to assist in landscape analysis and reclamation. To achieve sustainable development, reclamation projects should reinforce landscape character by taking into consideration the aesthetics and spirit of the place, and integrating the pre-industrial existence in the new landscape. This is the reason why it should be emphasized that the interlocking relationship between design management and aesthetic function is a particularly important feature of any design process [33], where computer simulations play an important role in enabling the development of projects that better adapt to the existing landscape.

The realized aesthetic study as well as the SWOT analysis helped in the assessment of the impacts that the implantation of a reclamation project would have on this landscape, constituting an important instrument to evaluate the cost-benefit relation and the feasibility of implementation of any project.

Thus, it is possible to conclude that the SWOT analysis of this post-industrial landscape combined with the aesthetic analysis demonstrated that there is a truly positive cost-benefit relation in its reclamation, not only because it permits the rehabilitation of a significant industrial heritage but also because it enables urban redevelopment by reusing derelict spaces in spite of consuming new ones. 
The presented landscape evaluation method could help landscape architects, planners and other professionals involved in the design of sustainable landscapes with aesthetic, cultural and social values. It could also enrich the decision-making process and help governmental officials to take appropriate decisions. Furthermore, the incorporation of aesthetic concepts in landscape reclamation may help minimize its visual impacts, enabling the creation of more consensual design options.

\section{ACKNOWLEDGEMENTS}

We would like to acknowledge financial support given to Luís Loures from the Fundação para a Ciência e a Tecnologia (FCT) (SFRH/BD/29700/2006 - PhD grant). We thank the Faculty of Engineering of Natural Resources of the University of Algarve and the Municipality of Lagoa for advice and guidance.

\section{REFERENCES}

[1] Al-Kodmany, K., Using web-based technologies and geographic information systems in community planning. J. Urban Technol., 7, pp. 1-30, 2002.

[2] Bishop, I. \& Hulse, D., Prediction of scenic beauty using mapped data and geographic information systems. Landscape and Urban Planning, 30, pp. 59-70, 1994.

[3] Buckley, D., Ulbricht, C. \& Berry, J., The virtual forest: advanced 3-D visualization techniques for forest management and research. ESRI 1998 User Conference, San Diego, California, 1998.

[4] Crawford, D., Using remotely sensed data in landscape visual quality assessment. Landscape and Urban Planning, 30, pp. 71-81, 1994.

[5] Daniel, T., Aesthetic preference and ecological sustainability. Forests and Landscapes: Linking Ecology, Sustainability and Aesthetics, eds S.R.J. Sheppard \& H.W. Harshaw, CABI Publishing: Oxford, pp. 15-30, 2001.

[6] Malczewski, J., GIS-based land-use suitability analysis: a critical overview. Prog. Plan., 62, pp. 3-65, 2004.

[7] Orland, B., Visualisation techniques for incorporation in forest planning geographic information systems. Landscape and Urban Planning, 30, pp. 83-97, 1994.

[8] Panagopoulos, T., The role of geographic information systems in visual landscape management and visual impact assessment. Proc. Int. Conf. Forest Research: A Challenge for an Integrated European Approach, ed. K. Radoglou, 27 September, Thessaloniki, Greece, pp. 79-82, 2001.

[9] Panagopoulos, T. \& Hatzistathis, A., Early growth of Pinus nigra and Robinia pseudacacia stands: contributions to soil genesis and landscape improvements on lignite spoils in Ptolemaida. Landscape and Urban Planning, 32, pp. 19-29, 1995.

[10] Parsons, R., Tassinary, L., Ulrich, R., Hebl, M. \& Grossman-Alexander, M., The view from the road: implications for stress recovery and immunization. J. Environ. Psychol., 18, pp. 113-140, 1998.

[11] Lothian, A., Landscape and the philosophy of aesthetics: is landscape quality inherent in the landscape or in the eye of the beholder? Landscape and Urban Planning, 44, pp. 177-198, 1999.

[12] Galofaro, L., Artscapes - Art as an Approach to Contemporary Landscape, Editorial Gustavo Gili: Barcelona, 2003.

[13] Langhorst, J., Rising from ruins: post-industrial sites between abandonment and engagement. Edinburgh, Scotland, 2004.

[14] Garcia, L., Hernandez, J. \& Ayuga, F., Analysis of the materials and exterior texture of agroindustrial buildings: a photo-analytical approach to landscape integration. Landscape and Urban Planning, 74, pp. 110-124, 2006. 
[15] Burley, J., Prospect. Landscape Architecture, 79(5), pp. 120-129, 1989.

[16] Loures, L., Horta, D., Santos, A. \& Panagopoulos, T., Strategies to reclaim derelict industrial areas. WSEAS Transactions on Environment and Development, 2(5), pp. 599-604, 2006.

[17] Corner, J., Ecology and landscapes as agents of creativity. Ecological Design and Planning, eds G.F. Thompson \& F.R. Steiner, John Wiley \& Sons, Inc.: New York, pp. 82-83, 1996.

[18] Loures, L. \& Panagopoulos, T., Sustainable reclamation of industrial areas in urban landscapes. Sustainable Development and Planning III, eds A. Kungolas, C.A. Brebbia, \& E. Beriatos, WIT Press: Southampton, 2007.

[19] Santos, A., Horta, D., Loures, L. \& Panagopoulos, T., Biophysical, cultural and aesthetics contributions in landscape reclamation. WSEAS Transactions on Environment and Development, 2(6), pp. 904-908, 2006.

[20] Abreu, A., Caracterização do Sistema Biofísico com Vista ao Ordenamento do Território, $\mathrm{PhD}$ Thesis, University of Évora, Évora, Portugal, 1989.

[21] Daniel, T., Whither scenic beauty. Visual landscape quality assessment in the 21 st century. Landscape and Urban Planning, 54, pp. 267-281, 2001.

[22] Canter, L., Environmental Impact Assessment, McGraw-Hill International Editions: Singapore, 1996.

[23] Panagopoulos, T. \& Vargues, P., Visual impact assessment of a golf course in a Mediterranean forest landscape. Patterns and Processes in Forest Landscapes, September 26-29, Bari, Italy, pp. 279-285, 2006.

[24] Martins, J., Estudo histórico-monográfico da freguesia de Ferragudo do concelho de Lagoa, Algarve em Foco Editora: Faro, 1990.

[25] Loures, L., \& Panagopoulos, T., Recovering derelict industrial landscapes in Portugal: past interventions and future perspectives. Proceedings of the Int. Conf. on Energy, Envir., Ecosystems and Sustainable Development, July 24-26, Agios Nikolaos, Crete Island, Greece, pp. 116-121, 2007.

[26] Colardelle, M., Les acteurs de la constituition du patrimoine: travailleurs, amateurs, professionnels. Actes des entretiens du patrimoine [Patrimoine et passions identitaires], Fayard: Paris, pp. 123-135, 1998.

[27] Davallon, J., Micoud, A. \& Tardy, C., Vers une évolution de la notion de patrimoine? L'esprit des lieux - le patrimoine et la cité, eds Daniel J. Grange \& Dominique Poulot, Presses Universitaires de Grenoble: France, 1997.

[28] Ashworth, G.J., From history to heritage - from heritage to identity. In search of concepts and models. Building a New Heritage. Tourism, Culture and Identity in the New Europe, eds Greg Ashworth \& P. Larkham, Routledge: London and New York, pp. 13-30, 1994.

[29] Fortuna, C., Destradicionalização e imagem da cidade - o caso de Évora. Cidade, Cultura e Globalização, ed. C. Fortuna, Celta: Oeiras, pp. 231-257, 1997.

[30] Peixoto, P., Imagens e Usos do Património Urbano no Contexto da lobalização, Tese de mestrado em sociologia, Faculdade de Economia da Universidade de Coimbra, 1997.

[31] US Department of Agriculture, Forest Service, The visual management system (Chapter 1). National Forest Landscape Management, Vol. 2, USDA Handbook 462, USDA: Washington, DC, 1974.

[32] Hatzistathis, A. \& Ispikoudis, I., Nature Protection and Landscape Architecture, Giahudi-Giapuli: Thessaloniki, 1992 (in Greek).

[33] Lyle, J.T., Design for Human Ecosystem, Van Nostrand Reinhold Comp., Ltd.: New York, 1985. 